\title{
Implementing Forward, Backward Chaining and Certainty Factor in Responsive Web-Based Expert System of Cow Disease
}

\author{
Rizki Wahyudi ${ }^{1}$, Wisnu Dwi Prasetyo ${ }^{2}$ \\ ${ }^{1}$ Teknik Informatika, STMIK Amikom Purwokerto, Banyumas, Indonesia \\ ${ }^{2}$ Sistem Informasi, STMIK Amikom Purwokerto, Banyumas, Indonesia \\ Jl. Letjen Polisi Sumarto Watumas Purwanegara Purwokerto, Banyumas, Indonesia \\ rizkiw@amikompurwokerto.ac.id, wisnupras@gmail.com
}

\begin{abstract}
This research aims to design and build expert systems of cow disease to assist farmers in identifying cattle diseases. A large number of cattle in Banyumas is not matched by the number of veterinarians, the Department of Fisheries and Livestock (DINKANAK). Banyumas records 961 cases of sick cows in 2016. This expert system is expected to assist cattle ranchers to identify cow disease and symptom-based remedies illness-symptoms. By using Inference Forward and Backward chaining which is a search method or tracking technique by using information from breeders, and Certainty Factor is used to accommodate the uncertainty of thinking of a data expert that is Doctor the process of extracting knowledge by interview. In this research system development using ESDLC (Expert System Development Life Cycle) with stages of Planning, Knowledge Acquisition, Implementation, and Evaluation. Testing is done with two approaches are Alpha Testing and Beta Testing. Alpha Testing conducted on the developer side to test the functional system using Black Box Testing method result all functional system can function well. Beta Testing is aimed at user acceptance by a Questionnaire method yields an average score of 76\% or usability and the quality of system information is easy to.
\end{abstract}

Keywords - Expert System, Forward Chaining, Backward chaining, Certainty Factor, ESDLC

\section{INTRODUCTION}

Cows are an important commodity for Indonesia, Banyumas Regency is one of the regions that have a large enough livestock potential with superior products including dairy cows and beef cattle. The development of beef cattle in Banyumas in 2014 was 12,247 and experienced an increase in 2015 to 15,886 [1]. Based on data from DINKANAK in Banyumas Regency, there were 8 doctors in Banyumas who were scattered in slaughterhouses Sokaraja, Purwokerto, Ajibarang, animal health posts in Cilongok, Banyumas and in the Banyumas District Office 3 veterinarians, very significant differences in the number of animals and Number of Doctors that is, besides the relatively high examination costs make farmers reluctant to check their livestock. Some farmers rely on experience in handling cattle that experience symptoms of a disease. Based on data obtained from DINKANAK Banyumas District, there were 39 types of diseases that occurred in Banyumas District with 961 cases in 2016 [2].

The limited knowledge of breeders about cow disease, which only relies on experience previously experienced in handling cattle that experience symptoms of a disease. Lack of information about cow disease causes farmers to misdiagnose. Based on information from veterinarians, there was a case of a farmer diagnosing cows with cystic disease (Septicaemia Epizooticae), so that farmers treat cows based on their illness, but after being examined by a doctor the illness is pneumonia. This misdiagnosis causes the disease to get worse. Such conditions need to be prevented so that farmers do not experience losses.

The existing cattle breeders in Banyumas Regency consist of 22 sub-districts, if there are cows affected by the disease, farmers usually report to veterinarians by telephone or visit animal health posts, a considerable distance is a constraint for farmers and veterinarians to treat cows that are afflicted with the disease. To overcome the problem of cattle farmers in Banyumas Regency an expert system was created to diagnose cow disease. Expert systems are computer systems that can mimic the ability of an expert, in this case, the animal system. It is expected that this expert system provides information about various types of diseases that attack cattle and their treatment.

From the results of Sasmito's research [3] which aims to create an expert system application in agricultural areas, namely to diagnose pests and horticultural diseases, including shallots and chili by implementing the Forward Chaining and Backward chaining methods and rule-based reasoning as a search technique in the knowledge base ( knowledge base). This system makes it easier for users to use the application because it has 2 choices in making the diagnosis process with the two inference techniques so that users also get more specific diagnosis results.

Other research expert systems by applying forward and backward chaining. The system is driven by the facts that exist to lead to conclusions. Facts are obtained from the patient's physical condition, or referred to as symptoms. In the design of this expert system, it is necessary to extract knowledge from experts, in this case, a doctor. The process of extracting knowledge by means of interviews. Based on the analysis, this expert system has 
a percentage of system feasibility to be used by laymen is $85.4 \%$. Besides that, based on the results of the questionnaire, the ease of this system also gets a large percentage as well [4].

A responsive website is a technique used to make the website layout adjust to the appearance of the visitor's device. A responsive website is an approach that provides site design capabilities in adapting to user behavior and site environment. Which is based on screen size, screen orientation and site container Lutfi \& Wahyudi [5]. The responsive Website works consist of a combination of flexible frames and displays, as well as the use of creative CSS (Cascading Style Sheet) systems. So that if the user moves from one device to another, the site will change to the right resolution [6].

Based on the description of the problems and previous research studies, this research will create an expert system that accommodates two Forward Inference and Backward Chaining Techniques and adds Certainty Factor method to overcome the uncertainty of expert thinking and with a responsive web-based system design, the user can access the device different from the adjusting display.

\section{RESEARCH METHODS}

The expert system for diagnosing cow disease is developed using Computer Based System Engineering based on the principle of the Expert System Development Cycle / ESDLC (Expert System Development Life Cycle). ESDLC consists of planning, knowledge acquisition, implementation, and evaluation.

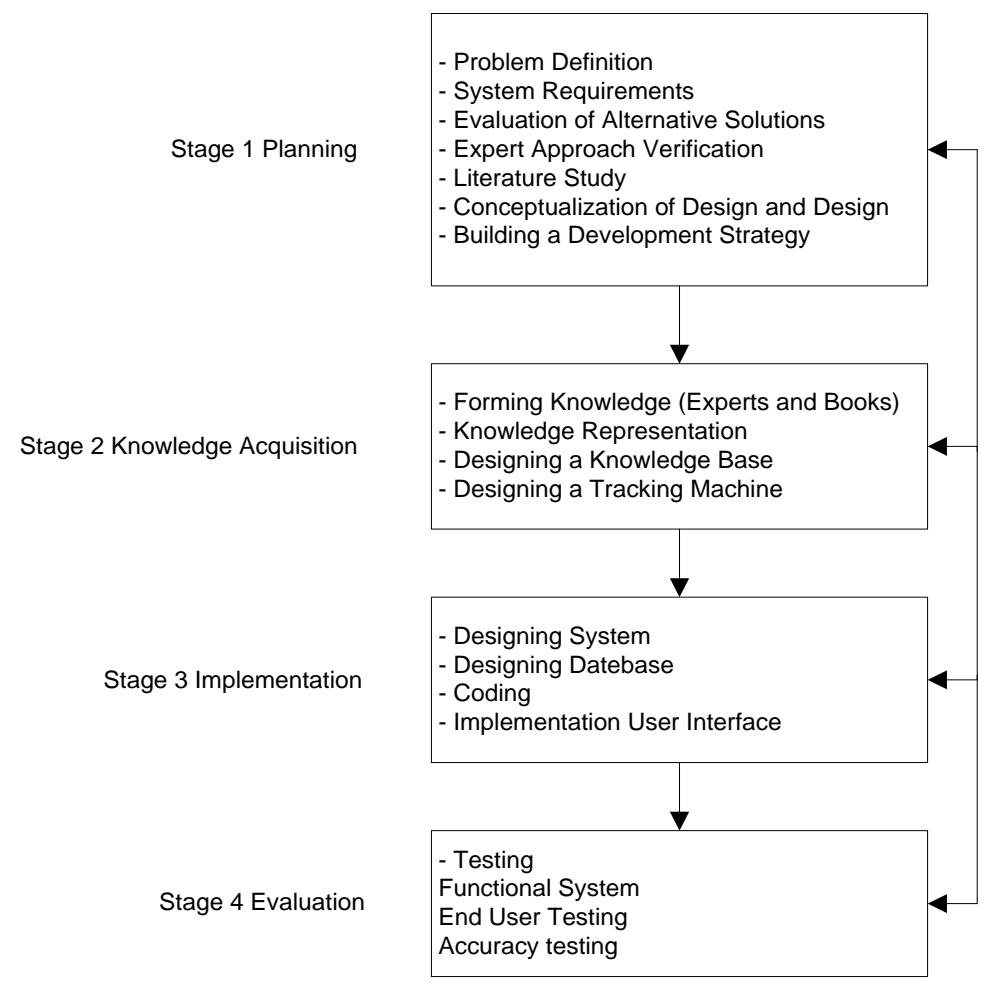

Figure 1. Adaptation of Expert System Development Life Cycle (ESDLC)

The process of making a cow disease diagnosis expert system using the forward and backward chaining methods rule-based reasoning is as follows:

a. Choose the object of research that will be applied to the expert system, namely DINKANAK Purwokerto.

b. Collect and identify the symptoms of cow disease, types of cow disease, and how to treat each type of cow disease in DINKANAK Purwokerto.

c. Analyze the type of cow disease that exists by tracing the symptoms of cow disease. Furthermore, a search is conducted to ascertain whether the symptoms of cow disease and the type of cow disease can be accommodated by the expert system by providing the best solution that must be taken or not.

d. The selection of experts who will be acquired by the knowledge to be interviewed and their work observed in the form of practical experience and understanding of the symptoms and types of cow disease. 
e. Make input and output design. Expert system input in the form of symptoms of cow disease that uses information provided by cattle farmers, while the output is in the form of cow disease and treatment methods.

f. expert system design diagnosis of cow disease is divided into three parts, namely interface, application and output. This interface can be used by the user to interact with expert system applications, needed to access the information objects needed.

The application part of this expert system contains knowledge and inference engine. All symptoms and types of cow disease and their rules are stored in the knowledge base. To bridge the existing interface and knowledge base, the inference engine is the steering wheel. All inputs in the form of symptoms of cow disease will be associated with the appropriate type of cow disease. The output of this expert system is the type and method of treatment of cow disease.

\section{RESULT AND DISCUSSION}

\subsection{System analysis.}

Development of a website-based Cow Disease Expert System using the Expert System Development Life Cycle (ESDLC) method.

\section{a. Planning Phase Terms}

This stage is the stage of setting goals, requirements and system requirements to solve problems.

1. System Objectives

This system aims to assist cattle farmers in diagnosing cow disease, and how to treat it.

\section{b. Terms of Information}

Website-based Cow Disease Expert System Development has several requirements which include completeness of data, software, and knowledge from experts in cattle disease. The complete data are:

\section{1) Symptoms of Disease Data}

Symptoms of cow disease experienced by cattle are: decreased appetite, fever, weakness, lethargy, inflammation of the milk ducts, milk out of normal, red milk water glands and when touched feels hot, if milked out milk clots, liquid out from eyes and nose, excessive saliva, trembling of the cow's body, limb stiffness to limping, feather loss, difficulty breathing, Cows often coughing, no signs of animals being attacked by brucella spp bacteria, pale mucous membranes, continuous tears, stiff and thick skin, left abdomen expands, abnormal voiced cows, discharge/mucus from the vagina, rapid breathing, around wet mouth, mucous membranes and eye valves become swollen, eye mucosa and nose experience congestion, gray skin surface, swelling in joints (Hygroma), red urine, white and liquid stools, possible opacity of the eyes, eyes and nose out mucopurulent discharge, purulent on the skin, frequent farts, pregnant women can experience a miscarriage / abortion at the age of pregnancy above 4 months, miscarriage in pregnant animals 3 weeks, cows look weak and dehydrated, eye drops may become mucopurulent, superficial lympe glands swollen, rubbed body rubbing on the wall of the cage, in males occurs Orchitis and infertility, disruption of respiration and audible snoring, the kidneys appear striped and skinny cows

\section{2) Data Diagnosis}

Diagnostic data is a diagnosis that is filled in by the veterinarian DINKANAK. Diagnosis also contains ways to treat Mastitis, Ephemeral Fever (Three-day fever), Scabies, Bloat, Pneumonia (Pneumonia), Brucellosis (infectious Kluron), Septicemia Epizooticae (Bull Cattle), Leptospirosis, Colibacillosis, Pink Eye and Malignant Catarrhal Fever.

3) Data relations

Relationship data is data that is used to connect diseases and diagnoses so that decision trees can work. The data comes from experts, books and extension modules. The following are Table 2. of disease relations and diagnosis.

Table 2. Table of Diseases

\begin{tabular}{ccll}
\hline No & \multicolumn{1}{c}{ Disease } & Symptoms & Treatment \\
\hline 1 & Mastitis & $\begin{array}{l}\text { Decreased appetite, Inflammation in the } \\
\text { ducts of milk The milk out is not normal, }\end{array}$ & $\begin{array}{l}\text { End the period of cow lactation, brood } \\
\text { Spectrum antibiotics, Phenicol Chloram }\end{array}$
\end{tabular}




\begin{tabular}{|c|c|c|c|}
\hline No & Disease & Symptoms & Treatment \\
\hline & & $\begin{array}{l}\text { the milk gland is red milk and when } \\
\text { touched feels hot, When milked out milk } \\
\text { clots }\end{array}$ & $\begin{array}{l} \pm \quad 4 \quad \mathrm{mg} / \mathrm{kg} \quad \text { B.B.I.M, Penicillin, } \\
\text { Streptomycin } \pm \text { 5-8 mg/kg B.B.I.M. }\end{array}$ \\
\hline 2 & $\begin{array}{l}\text { Ephemeral Fever } \\
\text { (Three days of } \\
\text { fever) }\end{array}$ & $\begin{array}{l}\text { Fever, Exit fluid from the eyes and nose, } \\
\text { Excessive saliva, the body of the cow } \\
\text { trembling The stiffness of the limbs until } \\
\text { limping }\end{array}$ & $\begin{array}{l}\text { Administration of antibiotics, } \\
\text { symptomatic drugs. }\end{array}$ \\
\hline 3 & Scabies & $\begin{array}{l}\text { Gray-colored skin surface, festering on the } \\
\text { skin, rubbing the body on the cage wall, } \\
\text { stiff and thick skin, Bulu fall out }\end{array}$ & $\begin{array}{l}\text { Giving Antihistamines, Apply steroid } \\
\text { cream to the surface of the skin affected } \\
\text { by scabies. To reduce the itching give } \\
\text { steroid pills. }\end{array}$ \\
\hline 4 & Bloat & $\begin{array}{l}\text { Appetite decreases, Ngentut often occurs, } \\
\text { Difficulty breathing, left abdomen } \\
\text { expands. }\end{array}$ & $\begin{array}{l}\text { Giving Anti Bloat and Wonder } \\
\text { Athympanicum melted. }\end{array}$ \\
\hline 5 & Pneumonia & $\begin{array}{l}\text { Decreased appetite, Fever, thin cow, } \\
\text { abnormal voice cows, Cows often cough }\end{array}$ & $\begin{array}{l}\text { Antibiotic vaccine, borogluconate } \mathrm{Ca} \text { and } \\
\text { regular vitamin } \mathrm{C} \text { intake during the } \\
\text { treatment period. }\end{array}$ \\
\hline 6 & $\begin{array}{l}\text { Brucellosis } \\
\text { (Kluron menular) }\end{array}$ & $\begin{array}{l}\text { Happened swelling in the joints ( hygroma } \\
\text { ), patients bunting can suffer a miscarriage } \\
\text { / abortus at the age of kebuntingan above } \\
\text { four months, in stud happened orchitis } \\
\text { and kemajiran, no sign of animals with } \\
\text { bacteria brucella spp, out the flow of / } \\
\text { tympanic from the vagina }\end{array}$ & $\begin{array}{l}\text { After a cow has miscarried, it is expected } \\
\text { that the farmer reports to the livestock } \\
\text { service, because the disease requires } \\
\text { special examination and through } \\
\text { laboratory tests. }\end{array}$ \\
\hline 7 & $\begin{array}{l}\text { Septicaemia } \\
\text { Epizooticae (Sapi } \\
\text { Ngorok) }\end{array}$ & $\begin{array}{l}\text { Swelling in the joints (Hygroma), } \\
\text { pregnant women can experience } \\
\text { miscarriage/abortion at a gestational age } \\
\text { above } 4 \text { months. In males, there is orchitis } \\
\text { and infertility. There is no sign of animals } \\
\text { having bacterial Brucella spp, } \\
\text { discharge/mucus from the vagina }\end{array}$ & $\begin{array}{l}\text { Decreased appetite Fever, Limp, } \\
\text { lethargy, Respiratory disorders and } \\
\text { audible snoring, Fast breathing }\end{array}$ \\
\hline 8 & Leptospirosis & $\begin{array}{l}\text { Decreased appetite, Fever, Red urine, } \\
\text { Miscarriage in pregnant animals } 3 \text { weeks, } \\
\text { In the kidneys appear striped }\end{array}$ & $\begin{array}{l}\text { Decreased appetite, Fever, Red urine, } \\
\text { Miscarriage in pregnant animals } 3 \text { weeks, } \\
\text { In the kidneys appear striped }\end{array}$ \\
\hline 9 & Colibacillosis & $\begin{array}{l}\text { The stool is white and liquid, the cow } \\
\text { looks weak and dehydrated, the mucous } \\
\text { membrane is pale, around the mouth is } \\
\text { wet. }\end{array}$ & $\begin{array}{l}\text { The stool is white and liquid, the cow } \\
\text { looks weak and dehydrated, the mucous } \\
\text { membrane is pale, around the mouth is } \\
\text { wet. }\end{array}$ \\
\hline 10 & Pink Eye & $\begin{array}{l}\text { Mucous membranes and eye valves } \\
\text { become swollen Possible opacity in the }\end{array}$ & $\begin{array}{l}\text { Mucous membranes and eye valves } \\
\text { become swollen Possible opacity in the }\end{array}$ \\
\hline & & $\begin{array}{l}\text { eyes, Eye drops may become } \\
\text { mucopurulent, continuous tears }\end{array}$ & $\begin{array}{l}\text { eyes, Eye drops may become } \\
\text { mucopurulent, continuous tears }\end{array}$ \\
\hline 11 & $\begin{array}{l}\text { Malignant } \\
\text { Catarrhal Fever }\end{array}$ & $\begin{array}{l}\text { Fever, eye mucosa, and nose experience } \\
\text { congestion. Eyes and nose run out } \\
\text { mucopurulent. Lymph gland, superficial }\end{array}$ & $\begin{array}{l}\text { Fever, eyes and nose experience } \\
\text { congestion. The eyes and nose run out, } \\
\text { the lymph gland. }\end{array}$ \\
\hline
\end{tabular}

\section{1) Officer Data}

Officer data is data to store officers who will $\log$ into the system. Login is required to verify user data that will enter the system. Because those who can enter and manage disease data, diagnoses and relationships are veterinarians.

\section{c. System Requirements Analysis}

The consultation process will take place online. Farmers will access the website and consult their livestock. Doctors only enter data on diseases, symptoms, and relationships that later the expert system will work in forming a decision tree and the farmer conducts consultations on the expert system that has been created. 
1) This Decision Tree is made using the Best First Search method to guide search to the node where the solution is located.

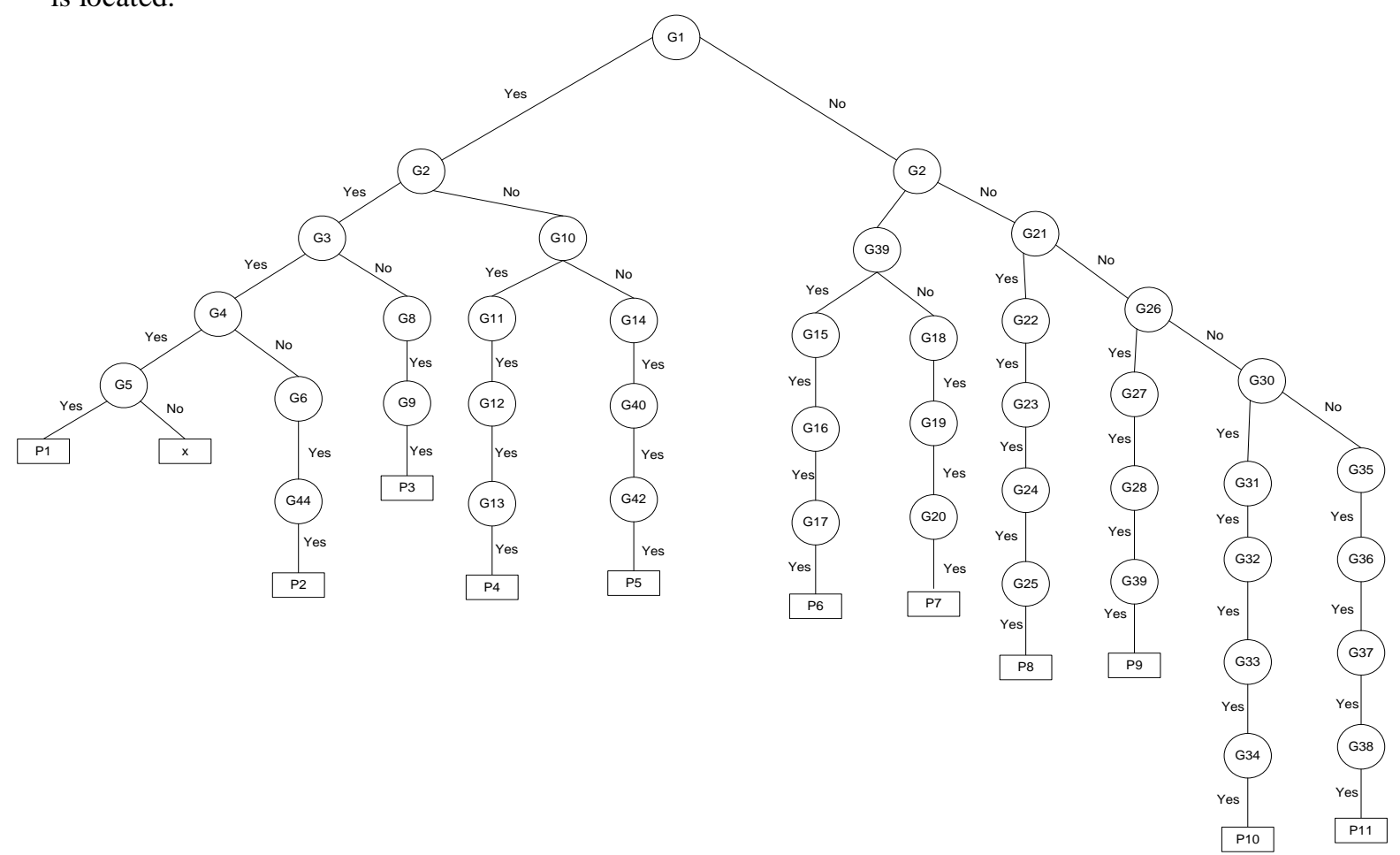

Description:

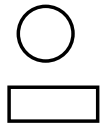

Symptoms

Figure 3. Decision Tree

\section{Disease}

1) Production Procedures for Cattle Disease

Table 3. describes the rules of production presented in the rules in the form of a state of affairs and action (condition and action).

Table 3. Rules for Cow Diseases

\begin{tabular}{cl}
\hline No & \multicolumn{1}{c}{ Rules for Cow Diseases } \\
\hline 1 & IF Decreased appetite, Inflammation in the ducts of milk The milk out is not normal, the milk gland is \\
red milk and when touched feels hot, When milked out the milk clots Then Mastitis \\
2 \\
IF Fever, Exit fluid from the eyes and nose, Excessive saliva, Excessive saliva, Motion stiffness to \\
Then Ephemeral Fever limp (Three-day fever) \\
3 IF Gray-colored skin surface, festering on the skin, rubbing the body on the cage wall, stiff and thick \\
skin, Bulu fall out Then Scabies \\
4 IF Appetite decreases, Ngentut often occurs, Difficulty breathing, left abdomen expands. Then Bloat \\
5 IF Decreased appetite, Fever, thin cow, abnormal voice cows, Cows often cough Then Pneumonia \\
6 IF Swelling in the joints (Hygroma), pregnant women can experience miscarriage/abortion at a \\
gestational age above 4 months. In males, there is orchitis and infertility. There is no sign of animals \\
having bacterial Brucella spp, discharge/mucus from the vagina Then Brucellosis \\
IF Decreased appetite Fever, Limp, lethargy, Respiratory disorders and audible snoring, Fast breathing \\
Then Septicaemia Epizootic \\
IF Decreased appetite, Fever, Red urine, Miscarriage in pregnant animals 3 weeks, In the kidneys \\
appear striped Then Leptospirosis \\
IF Stool is white and liquid, the cow looks weak and dehydrated, the mucous membrane is pale, around \\
the mouth is wet. Then Colibacillosis \\
IF IF Mucous membranes and eye valves become swollen Possibly opacity to the eyes, Mole may \\
become mucopurulent, continuous tears Then Pink Eye
\end{tabular}




\begin{tabular}{cc}
\hline No & \multicolumn{1}{c}{ Rules for Cow Diseases } \\
\hline 11 & $\begin{array}{l}\text { IF Fever, eye mucosa, and nose experience congestion. Eyes and nose out mucopurulent, lymph gland, } \\
\text { superficial swelling. Then Malignant Catarrhal Fever }\end{array}$ \\
\hline
\end{tabular}

2. Calculation of Manual Certainty Factor Values

Certainty Factor Values are assigned to each symptom associated with a particular disease in the range/value range 0 to 1 . This value will represent an expert's belief in a symptom that has an impact on the occurrence of a cow disease.

Table 3. weighting of cattle diseases

\begin{tabular}{|c|c|c|c|c|}
\hline \multirow{2}{*}{ No } & \multirow{2}{*}{ Symptoms } & \multirow{2}{*}{ Disease } & \multicolumn{2}{|c|}{ Weighting } \\
\hline & & & MB & MD \\
\hline G1 & Decreased Appetite & Mastitis & 0.6 & 0.2 \\
\hline G9 & Inflammation Of The Ducts & Mastitis & 0.4 & 0.2 \\
\hline G10 & Milk Out Is Not Normal & Mastitis & 0.8 & 0.1 \\
\hline G11 & Red Milk Water Gland And When Felt Feels Hot & Mastitis & 0.8 & 0.2 \\
\hline G12 & When Milked, Milk Clots Out & Mastitis & 0.6 & 0.1 \\
\hline $\mathrm{G} 2$ & Demam & Ephhemeral Fever & 0.8 & 0.2 \\
\hline G14 & Fever & Ephhemeral Fever & 0.4 & 0.2 \\
\hline G15 & The Body Of A Cow Trembles & Ephemeral Fever & 0.4 & 0.2 \\
\hline G16 & Member Stiffness Until Limping & Ephemeral Fever & 06 & 0.2 \\
\hline G29 & Bulu Fall Out & Scabies & 0.8 & 0.1 \\
\hline G30 & Stiff And Thick Skin. & Scabies & 0.6 & 0.2 \\
\hline G31 & Gray Skin Surface. & Scabies & 0.6 & 0.2 \\
\hline G32 & Festering On The Skin. & Scabies & 0.6 & 0.2 \\
\hline G33 & Rubbing The Body On The Cage Wall & Scabies & 0.6 & 0.2 \\
\hline G13 & Hard To Breathe & Bloat & 0.8 & 0.1 \\
\hline G39 & The Left Abdomen Expands. & Bloat & 0.6 & 0.2 \\
\hline G41 & Often Fart. & Bloat & 0.4 & 0.1 \\
\hline G40 & Abnormal Voices & Pneumonia & 0.6 & 0.1 \\
\hline G43 & Thin Cow & Pneumonia & 0.8 & 0.1 \\
\hline G20 & There Is No Sign Of Animals Being Attacked By Brucella Spp & Brucellosis & 0.4 & 0.2 \\
\hline G21 & Runny / Mucus From The Vagina & Brucellosis & 0.8 & 0.2 \\
\hline G22 & Swelling In Joints (Hygroma) & Brucellosis & 0.6 & 0.2 \\
\hline G23 & $\begin{array}{l}\text { Pregnant Sufferers Can Experience A Miscarriage / Abortion } \\
\text { At Gestational Age Over } 4 \text { Months }\end{array}$ & Brucellosis & 0.4 & 0.2 \\
\hline G24 & In Males There Is Orchitis And Infertility & Brucellosis & 0.4 & 0.2 \\
\hline G42 & Miscarriage In Pregnant Animals 3 Weeks & Leptospirosis & 0.8 & 0.2 \\
\hline $\mathrm{G} 25$ & Pale Mucous Membranes. & Colibaclillosis & 0.8 & 0.1 \\
\hline G26 & Around The Wet Mouth. & Colibaclillosis & 0.6 & 0.2 \\
\hline G27 & Stool Is White And Liquid. & Colibaclillosis & 06 & 0.1 \\
\hline G28 & Cows Look Weak And Dehydrated. & Colibaclillosis & 06 & 0.1 \\
\hline G34 & Continuous Tears & Pink Eye & 06 & 0.1 \\
\hline G35 & The Mucous Membranes And Eye Valves Become Swollen & Pink Eye & 06 & 0.2 \\
\hline G36 & Opacity Is Likely To Occur In The Eye & Pink Eye & 06 & 0.2 \\
\hline G37 & Mole May Be mucopurulent & Pink Eye & 06 & 0.2 \\
\hline G38 & Liquid Discharge From The Eyes And Nose & Pink Eye & 06 & 0.2 \\
\hline G19 & Superficial Lymph Nodes Are Swollen. & $\begin{array}{l}\text { Malignant } \\
\text { Catarrhal Fever }\end{array}$ & 06 & 0.2 \\
\hline
\end{tabular}

The following is an example of calculating the value of the Scabies disease certainty factor:

Table 4. Calculation of CF values for Scabies

\begin{tabular}{llllc}
\hline \multirow{2}{*}{ No } & \multicolumn{2}{c}{ Symptoms } & \multirow{2}{*}{ Disease } & \multicolumn{2}{c}{ Weighting } \\
& & & MB & MD \\
\hline G29 & feathers fall out & Scabies & 08 & 0.1 \\
G30 & Stiff and thick skin. & Scabies & 06 & 0.2
\end{tabular}




\begin{tabular}{llllc}
\hline \multirow{2}{*}{ No } & \multicolumn{1}{c}{ Symptoms } & \multirow{2}{*}{ Disease } & \multicolumn{2}{c}{ Weighting } \\
& & MB & MD \\
\hline G31 & Gray skin surface. & Scabies & 06 & 0.2 \\
G32 & Festering on the skin. & Scabies & 06 & 0.2 \\
G33 & Rubbing the body on the cage wall & 06 & 0.2 \\
\hline
\end{tabular}

Formula [8] :

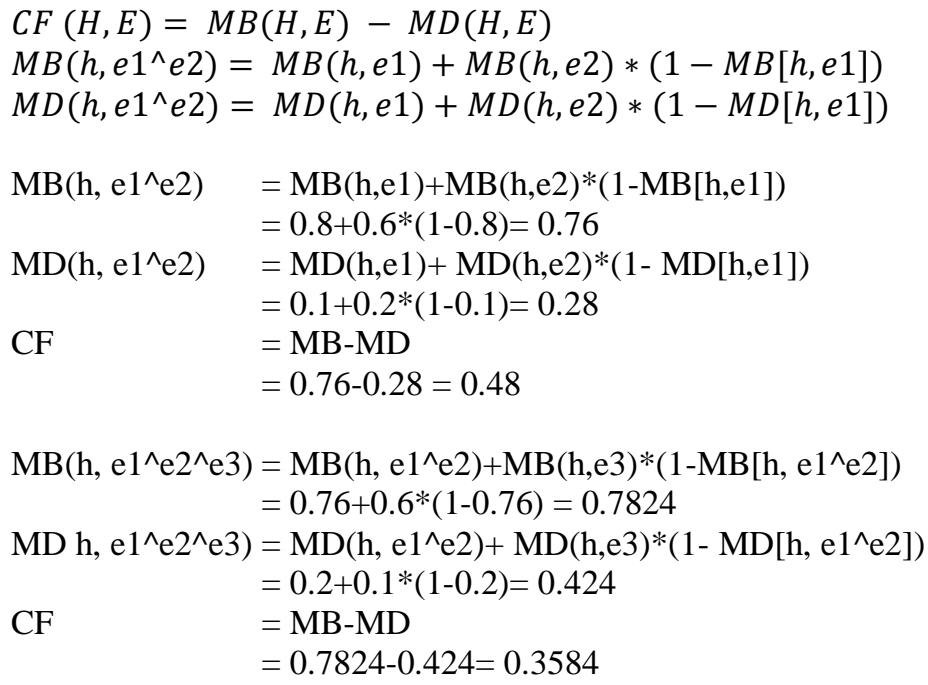

$\mathrm{MB}\left(\mathrm{h}, \mathrm{e} 1^{\wedge} \mathrm{e} 2^{\wedge} \mathrm{e} 3^{\wedge} \mathrm{e} 4\right)=\operatorname{MB}\left(\mathrm{h}, \mathrm{e} 1^{\wedge} \mathrm{e} 2^{\wedge} \mathrm{e} 3\right)+\mathrm{MB}(\mathrm{h}, \mathrm{e} 3) *\left(1-\mathrm{MB}\left[\mathrm{h}, \mathrm{e} 1^{\wedge} \mathrm{e} 2^{\wedge} \mathrm{e} 3\right]\right)$

$=0.7824+0.6 *(1-0.7824)=0,7703$

$\left.\mathrm{MD} \mathrm{h}, \mathrm{e} 1^{\wedge} \mathrm{e} 2^{\wedge} \mathrm{e} 3^{\wedge} \mathrm{e} 4\right) \quad=\operatorname{MD}\left(\mathrm{h}, \mathrm{e} 1^{\wedge} \mathrm{e} 2^{\wedge} \mathrm{e} 3\right)+\operatorname{MD}(\mathrm{h}, \mathrm{e} 3)^{*}\left(1-\mathrm{MD}\left[\mathrm{h}, \mathrm{e} 1^{\wedge} \mathrm{e} 2^{\wedge} \mathrm{e} 3\right]\right)$

$\mathrm{CF} \quad=\mathrm{MB}-\mathrm{MD}$$$
=0.7703-0.5392=0,2311
$$

Based on the calculation of one type of cow disease above, obtained the value of the certainty factor from the input of the symptoms that concluded that the type of cow disease suffered was Scabies with a value of 0.2311.

\section{Design}

Software design includes the design of software program making also includes data structures, software architectures, interface representations and coding procedures. The following design stages include:

a. Design Data Flow Diagram

Contexts diagram of cow disease expert system in Figure 4.

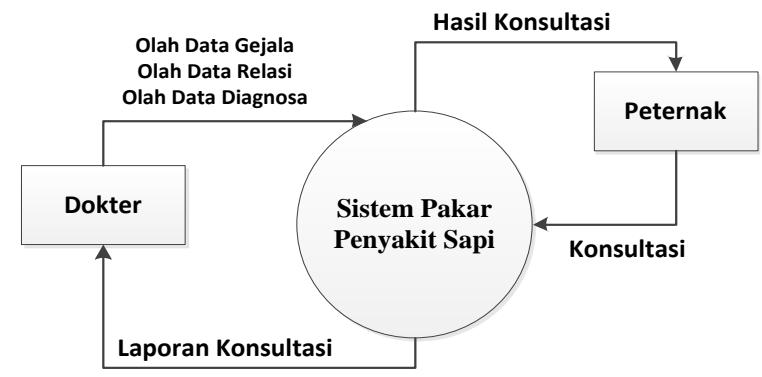

Figure 4. Contexts of the Cattle Disease Expert System Diagram

Description Figure 4. Contexts Diagram:

Doctors can manage symptoms of cow disease, diagnosis, and relationships, and reports that can be seen are only consultation history. While farmers can consult and get the results of the diagnosis from the consultation. 


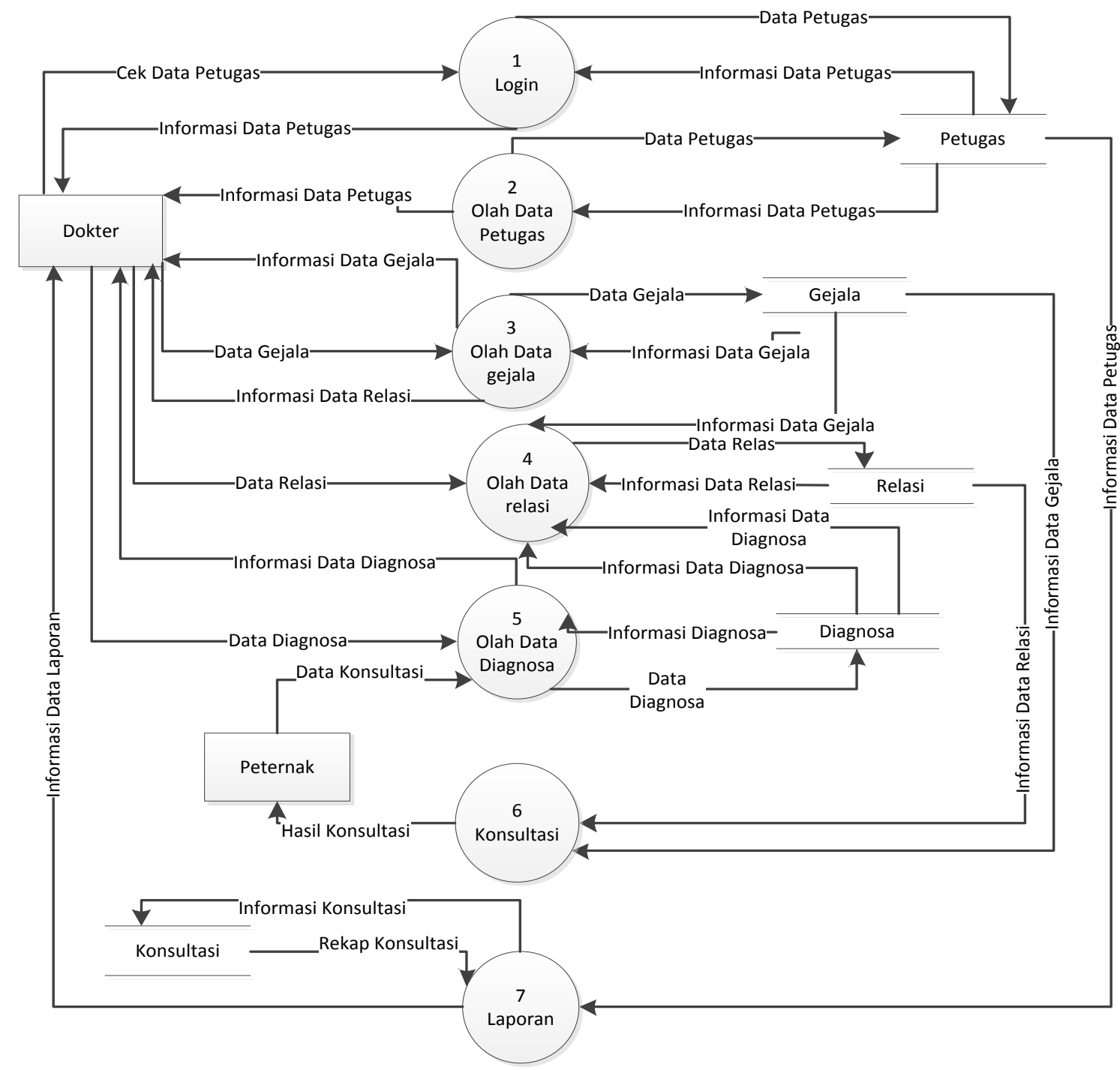

Figure 5. Data Flow Diagram level 1

Figure 5. In Data Flow Diagram level 1 there are 7 processes, namely:

a) Process 1, Login, the validation process of the user who will enter is the user who has registered before.

b) Process 2 , if the data officer is the data processing process of users who have registered for user verification and validation when logging in.

c) Process 3 of symptom data processing is data processing of disease symptoms in an expert system which is informed by a doctor.

d) Process 4, data processing relationships are data processing relationships between symptoms and diagnoses in the expert system inputted by experts or veterinarians.

e) Process 5, the diagnostic data processing is the process of processing disease diagnosis data in the expert system which is submitted by veterinarians.

f) Process 6, consultation carried out by farmers by answering the suitability of the symptoms of cow disease displayed.

g) Process 7, recap the report, which shows the constitution data periodically.

\section{d. Design Database}

Database design in making this application includes ERD (Entity Relationship Diagram) in the table structure and relationships between database tables of cow disease expert systems.

1) $E R D$ 


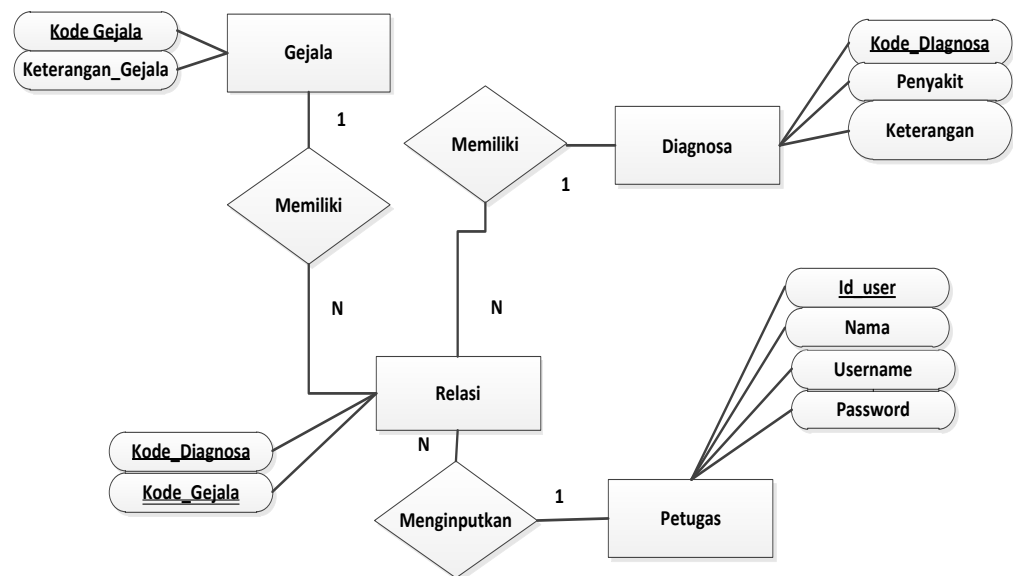

Figure 6. Entity Relationship Diagram

e. User Interface

1) The following Main Menu page is run using the Galaxy S4 Smartphone, to test the design flexibility when opening on a Mobile device.

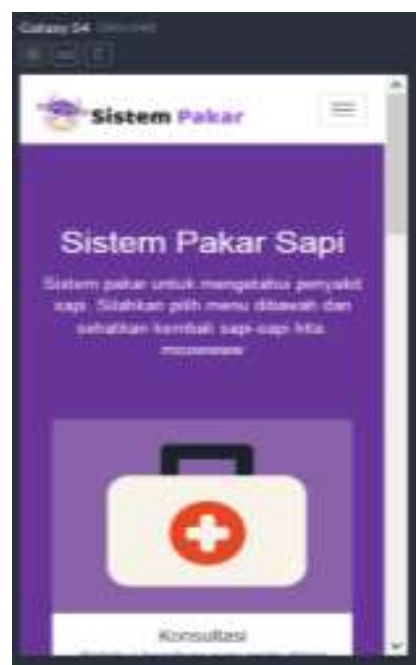

Figure 7. Main Menu Page

The main menu page is used to display menus in the application that will be carried out by the calling process. The menus contained in the Play Form above are masters consisting of Symptoms data pages, Diagnosis, Relations and Consultation pages.

2) Symptoms page

\section{Gejala}

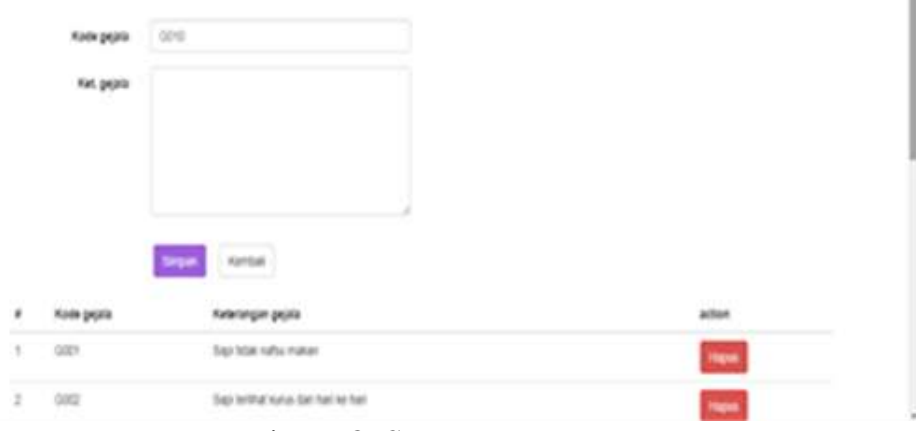

Figure 8. Symptoms page 
International Journal of Informatics and Computer Science (The IJICS) Vol 2 No 1, March 2018

ISSN 2548-8384 (online)

ISSN 2548-8449 (print)

Page: $7-19$

Symptom data page serves to enter data on symptoms of a disease.

3) Diagnosis page

\section{Diagnosa}
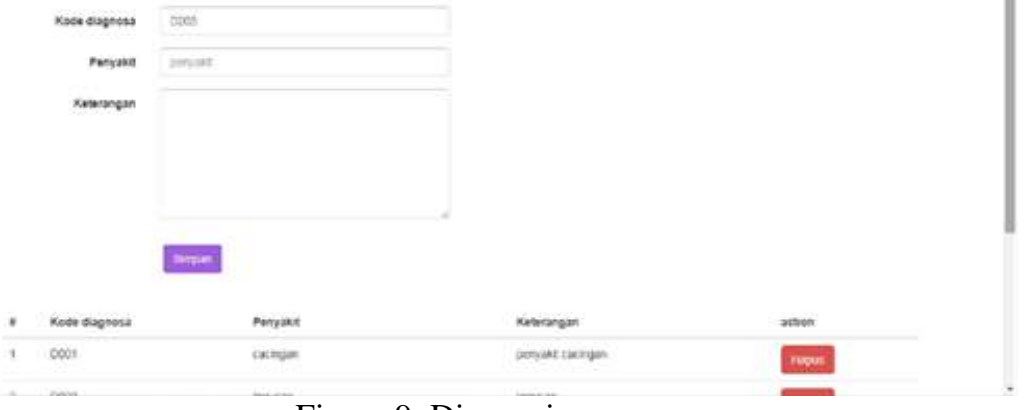

Figure 9. Diagnosis page

The diagnostic page is used to see the diagnosis given after consulting.

4) Relations page

\section{Relasi}

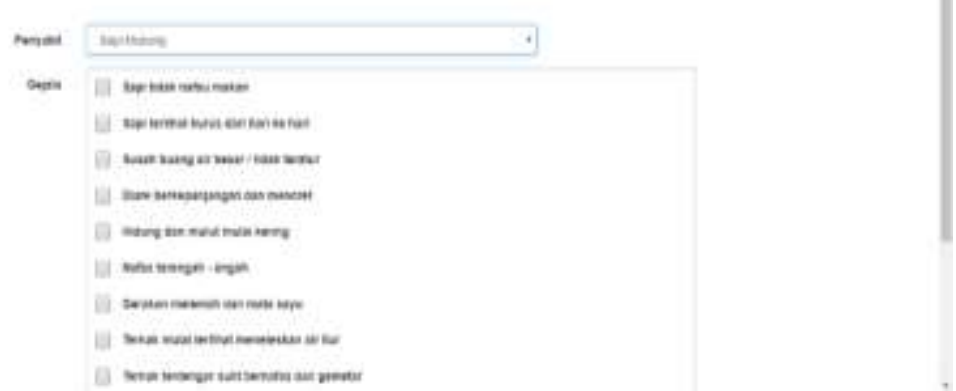

Figure 10. Relationship page

The relation page serves to provide information about the symptoms of an illness.

5) Consultation page

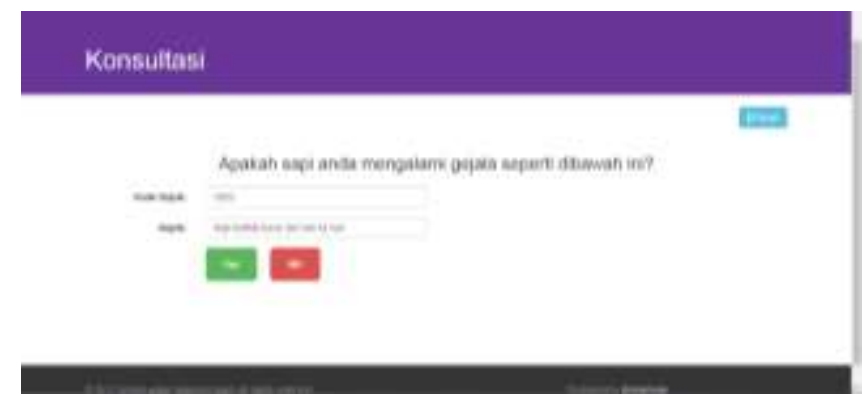

Figure 11. Cow Expert System Consultation Page

The consultation page serves to give questions to farmers about the symptoms experienced by sick cows.

\section{f. System Testing}

1) Alpha testing

Alpha testing is done on the developer side to test the functional system, this test is done using the Black Box method [9] [10], can be seen in the table below: 
Table 4. Black Box Testing Table

\begin{tabular}{clll}
\hline No & System Components Tested & \multicolumn{1}{c}{ Butir Uji } & \multicolumn{1}{c}{ Status } \\
\hline \multirow{2}{*}{1} & \multirow{2}{*}{ Login Form } & OK button & Success \\
& & Cancel button & Success \\
2 & Symptom Data Form & Save Button & Success \\
& & Back Button & Success \\
3 & Data Diagnosis Form & Save Button & Success \\
& & Back Button & Success \\
4 & Data Relations Form & Save Button & Success \\
& & Back Button & Success \\
5 & Consultation Data Form & Ok Button & Success \\
6 & Report Form & No button & Success \\
& & Print button & Success \\
\hline
\end{tabular}

In the Alpha Testing test, the expert system of cow disease was used for Black Box Testing. Black Box Testing is a step taken to test the functional system, run or execute a unit or module, then observe whether the results of the unit are in accordance with the process desired by Wahyudi, Utami, \& Arief [11]. In this Black Box Testing, only input data and see whether the output is in accordance with the expected process. The Black Box test results that all functional systems function properly.

\section{2) Validation Testing}

Accuracy testing is a technique to be able to see the performance of the existing expert system to provide analysis results on the diagnosis of cow disease based on the symptoms of the disease. The amount of data on the type of disease in the test 11 samples of expert system data analysis. The recommendation results obtained from calculations in the expert system are matched with the results of the analysis from the expert. The results obtained from testing the accuracy of expert systems are shown in Table 5.

Table 5. Validation Testing

\begin{tabular}{lllcc}
\hline No & Diagnosa Pakar & Diagnasa Sistem & Nilai Akurasi & $\%$ \\
\hline 1 & Mastitis & Mastitis & 1 & 100 \\
2 & Ephhemeral Fever (Demam tiga hari) & Ephhemeral Fever (Demam tiga & 1 & 100 \\
3 & Scabies & Scabies & 1 & 100 \\
4 & Bloat & Bloat & 1 & 100 \\
5 & Pneumonia (Radang paru-paru) & Pneumonia (Radang paru-paru) & 1 & 100 \\
6 & Brucellosis (Kluron menular) & Brucellosis (Kluron menular) & 1 & 100 \\
7 & Septicaemia Epizooticae (Sapi Ngorok) & Septicaemia Epizooticae (Sapi & 1 & 100 \\
8 & Leptospirosis & Ngorok) & 1 & 100 \\
9 & Colibaclillosis & Colibaclillosis & 1 & 100 \\
10 & Pink Eye & Pink Eye & 1 & 100 \\
11 & Malignant Catarrhal Fever & Malignant Catarrhal Fever & 1 & 100 \\
\hline
\end{tabular}

Based on Table 5. accuracy testing has been done with 11 data samples from the disease and produces values of accuracy according to the following calculations:

$$
\begin{gathered}
\text { Accuracy value }=\frac{\text { The amount of data is accurate }}{\text { Total data }} \times 100 \% \\
\text { Total data }=\frac{11}{11} \times 100 \%=100 \%
\end{gathered}
$$

Conclusion Expert system accuracy based on the 11 data tested is $100 \%$ indicating that this expert system can function properly in accordance with the expert analysis.

2) Beta Testing

Beta testing is done from the end user side, while the Beta test design will be tested with questionnaire techniques using Webqual 4 in terms of usefulness and quality of information [11], [12]. The sampling calculation uses the Slovin formula as follows:

$$
\text { Sample size }=\frac{\text { Population number }}{\left(1+\text { Population number } *(\text { fault tolerance limit })^{2}\right)}
$$


Likert scale formula:

$$
\text { Results }=\frac{\text { Total }}{\text { Respondents } * \text { Maximum score }} * 100
$$

The following details of the test results:

Sampling $1755 /\left(1+1755^{*}(0.1)^{2}\right)=326$

Table 5. Questionnaires and Likert scale results

\begin{tabular}{|c|c|c|c|c|c|c|}
\hline Questionnaire question & STS & TS & $\mathbf{C S}$ & $\mathbf{S}$ & SS & Hasil \\
\hline $\begin{array}{l}\text { Is the look of the cow consultation website design } \\
\text { attractive? }\end{array}$ & $6 \%$ & $7 \%$ & $14 \%$ & $28 \%$ & $44 \%$ & $79 \%$ \\
\hline $\begin{array}{l}\text { Is the Menu on the Cattle Consultation Website Easy } \\
\text { to Understand? }\end{array}$ & $5 \%$ & $8 \%$ & $19 \%$ & $35 \%$ & $32 \%$ & $76 \%$ \\
\hline Is the cattle consultation website easy to operate? & $3 \%$ & $10 \%$ & $20 \%$ & $38 \%$ & $27 \%$ & $75 \%$ \\
\hline $\begin{array}{l}\text { Does the cattle consultation website provide accurate } \\
\text { information such as a doctor's examination? }\end{array}$ & $4 \%$ & $9 \%$ & $23 \%$ & $35 \%$ & $27 \%$ & $\mathbf{7 4 \%}$ \\
\hline $\begin{array}{l}\text { The cow consultation website helps in overcoming the } \\
\text { distance of a doctor's practice? }\end{array}$ & $5 \%$ & $7 \%$ & $21 \%$ & $30 \%$ & $36 \%$ & $77 \%$ \\
\hline $\begin{array}{l}\text { Does the cattle consultation website provide } \\
\text { information that is easy to understand? }\end{array}$ & $6 \%$ & $10 \%$ & $21 \%$ & $36 \%$ & $25 \%$ & $73 \%$ \\
\hline
\end{tabular}

Description of Likert scale calculation:

Table 6. Likert scale

\begin{tabular}{cl}
\hline Scale & \multicolumn{1}{c}{ Description } \\
\hline $0 \%-19.99 \%$ & Very (Disagree, Bad or Less) \\
$20 \%-39.99 \%$ & Disagree or Not Good \\
$40 \%-59.99 \%$ & Enough or Neutral \\
$60 \%-79.99 \%$ & Agree, Good or Like \\
$80 \%-100 \%$ & Very (Agree, Good, Like) \\
\hline
\end{tabular}

In Table 6. Questionnaires and Likert scale results yield an average score of $76 \%$ or in terms of usefulness and quality of information easily understood.

\section{CONCLUSION}

\subsection{Conclusion}

a. An expert system has been designed and made a diagnosis of responsive website-based cow disease using the Forward, Backward Chaining and Certainty Factor methods to diagnose diseases and treatment of cattle.

b. The results of alpha testing were carried out using the Black Box method, proving that the functional cattle system expert system website could work well and the Beta Testing test results were carried out using a questionnaire consisting of 6 questions yielding an average score of $76 \%$ or the usefulness and quality of information. the system is feasible to implement.

\subsection{Suggestion}

As for some suggestions that can be submitted to develop this application in the form of: Diagnosis in the expert system is best added to treatment in alternative medicine.

\section{REFERENCES}

[1] Badan Pusat Statistik. 2015. Kabupaten Banyumas Dalam Angka Tahun. Banyumas.

[2] Dinas Dinas Perikanan dan Peternakan Banyumas. 2016

[3] Sasmito, Ganjar Wiro. 2017. Sistem Pakar Diagnosis Hama dan Penyakit Tanaman Hortikultura dengan Teknik Inferensi Forward dan Backward chaining. Jurnal Teknologi dan Sistem Komputer, 5 (2), 73.

[4] Suwarso, Budhi \& Dewi. 2015. Sistem Pakar untuk Penyakit Anak Menggunakan Metode Forward Chaining. Skripsi: Fakultas Teknologi Industri Universitas Kristen Petra 
International Journal of Informatics and Computer Science (The IJICS) ISSN 2548-8384 (online)

Vol 2 No 1, March 2018

ISSN 2548-8449 (print)

Page: $7-19$

[5] Marcotte, Ethan. (2015). Responsive Design. Diambl dari: https://alistapart.com/topic/responsive-design

[6] Lutfi, A. A., \& Wahyudi, R. (2017). Aplikasi Tracer Study Berbasis Website Responsive Pada Fakultas Pertanian Universitas Jendra Soedirman. Majalah Ilmiah INTI (Informasi Dan Teknologi Ilmiah), 13, 125-132.

[7] Giarratano, J. \& Riley, G. (2005). Expert System: Principles and Programming, 4th Edition, Publishing Company, Boston.

[8] Sibagariang, Swono. 2015. Sistem Pakar Diagnosa Penyakit Sapi Dengan Metode Certainty Factor Berbasis Android. Jurnal TIMES, Vol. IV No 2: 35-39.

[9] Alhammadi, D.A.A, 2010, Developing Expert System for Diabetes Mellitus Patients, Thesis, Department of Computer Science King Saud University, Riyadh.

[10] E, Turban. "Expert System and Applied Artificial Intelligence", Macmillan Publishing Company, New York, 1995

[11] Wahyudi, R., Utami, E., \& Arief, M. R. (2016). Sistem Pakar E-Tourism Pada Dinas Pariwisata D.I.Y Menggunakan Metode Forward Chaining, 17(2), 67-75.

[12] Yuhendra. 2008. Rekayasa Pengetahuan Pakar Berbasis Aturan Untuk Identifikasi Kerusakan Hardware. 